\title{
Reproduction of the fish community of Passa Cinco Stream, Corumbataí River sub-basin, São Paulo State, Southeastern Brazil
}

\author{
Rondineli, GR.* and Braga, FMS. \\ Departamento de Zoologia, Instituto de Biociências, \\ Universidade Estadual Paulista - UNESP, \\ Av. 24A, n¹515, Bela Vista, CP 199, CEP 13506-900, Rio Claro, SP, Brazil \\ *e-mail: giu@rc.unesp.br
}

Received August 12, 2008 - Accepted January 12, 2009 - Distributed February 28, 2010

(With 2 figures)

\begin{abstract}
The aim of this work was to evaluate the reproduction (verifying if there was reproductive activity and, if so, with what intensity) of the most abundant species of the fish community in Passa Cinco stream, in relation to the dry and wet season periods and to the longitudinal gradient, through the application of the reproductive intensity index (RII). The sample collection was carried out during one year with six samplings (May, July, September and November 2005, and January and March 2006) in five different points of Passa Cinco stream, contemplating sites of orders two to six. The following fishery equipment was used: a sieve, electric fishery equipment, gill nets and fish-traps. The values of the reproductive intensity index for the dry period were 2.86 and for the wet season 3.17, which indicates the wet season (November to March) as the period when most of the species reproduced. The values of the index for collection point were: 0.78 for site $1,3.56$ for site 2 and 2.89 for site 3 . Site 2 , which presented the highest value, was the main reproduction place for most of the species. The adults' prevalence in the analysed species suggests, in an isolated way, that those species use the system as a reproduction area. However, when that information was crossed with the values of RII, when intermediate values were considered, it is possible to state that the system is used by the species as much as a reproduction area as a feeding area.
\end{abstract}

Keywords: reproductive intensity index, High Paraná River basin.

\section{Reprodução da comunidade de peixes do Rio Passa Cinco, sub-bacia do Rio Corumbataí, Estado de São Paulo, Sudeste do Brasil}

\begin{abstract}
Resumo
O objetivo desse trabalho foi avaliar a reprodução (verificando se ocorreu atividade reprodutiva e com qual intensidade) das espécies mais abundantes da comunidade de peixes do Rio Passa Cinco em relação aos períodos de seca e cheia e ao gradiente longitudinal através da aplicação do índice de intensidade reprodutiva (IR). Seis amostragens foram realizadas em cinco pontos distintos do Rio Passa Cinco contemplando trechos de ordem dois a seis nos meses de maio, julho, setembro e novembro de 2005 e janeiro e março de 2006. Os apetrechos de pesca utilizados foram: peneira, pesca elétrica, redes de espera e covos. O valor do índice de intensidade reprodutiva para o período de seca foi de 2,86 e para o período de cheia 3,17 , o que indica a cheia (novembro a março) como o período em que a maioria das espécies se reproduziu. Os valores do índice por ponto de coleta foram: 0,78 para o ponto 1, 3,56 para o ponto 2 e 2,89 para o ponto 3 . O ponto 2 , que apresentou o maior valor, foi o principal local de reprodução para a maioria das espécies. O predomínio de adultos nas espécies analisadas sugere, de modo isolado, que essas espécies utilizam o sistema como área de reprodução. No entanto, quando essa informação foi cruzada com os valores de IR, que foram considerados valores intermediários, tem-se que o sistema é utilizado pelas espécies tanto como área de reprodução como de alimentação.
\end{abstract}

Palavras-chave: índice de intensidade reprodutiva, bacia do Alto Paraná. 


\section{Introduction}

Reproduction represents one of the most important aspects of species biology, because the recruitment and, consequently, the maintenance of viable populations depend on its success. According to Wootton (1984), fish reproductive success depends on where and when it reproduces and on the resources allocated for reproduction. In this way, reproduction should happen in the period of the year when descendant production is maximised.

The reproductive strategy of a species refers to the general pattern of reproduction presented, given by the group of responsible characteristics for reproductive success, in such a way as to guarantee the balance of the population. Considering that each species has its established distribution for a certain group of ecological conditions, it should present a single reproductive strategy and, for doing so, to present specific anatomical, physiologic, behavioural and energetic adaptations. Variations in environmental conditions can change in some of those characteristics. Those variable characteristics are reproductive tactics. Either the strategy or the reproductive tactics have an adaptive character (Wootton, 1989).

According to Vazzoler (1996), most Neotropical fish present a cyclical reproductive period. Light and temperature are the most common triggers since they begin or they control the rate of gonadal development, but other conditions (environmental, physiological and behavioural) are important in the period immediately previous to spawning (Bye, 1984). In fresh water, alterations in the water level and the sequence of dry and wet seasons are the main existing events (Lowe-McConnell, 1999).

Due to the close relationship between the maturation progress of oocytes and the increase of volume, which implies an increase in ovary weight, the gonadossomatic relationship (GR), that shows the percentage of gonads on individuals' total weight, is an efficient indicator of ovary functional state (Vazzoler, 1996). Also, the temporary variation of GR supplies information about the reproductive period of species or population (Nikolsky, 1963).

The reproductive intensity index (RII) (Vazzoler, 1996) considers the frequencies of the female gonads stages and the values of the gonadossomatic relationship (GR). Therefore, it makes it possible to state at what intensity spawning occurs in those environments.

The Passa Cinco Stream is relatively preserved, presenting the largest remaining forest fragment of the whole Corumbataí River sub-basin. The Passa Cinco Stream is considered one of the most important sources of water inserted in this sub-basin, a highly developed and industrialised area and degraded from the environmental point of view (Corvalán, 2005).

Several ichthyological studies have been carried out in Passa Cinco Stream (Viadanna, 1992; Gomiero, 2003; Cetra, 2003; Fragoso, 2005; Gerhard, 2005; Ferreira, 2004; Rondineli, 2007; Carmassi, 2008). Regarding the reproductive aspects of fish in that stream, the follow- ing work has been accomplished: Barbieri et al. (1983), Barbieri et al. (1985), Azevedo et al. (1988a, b), Barbieri and Barbieri (1989), Fragoso (2005), Gomiero and Braga (2007) and Rondineli (2007).

With the intention of contributing to the knowledge of reproductive aspects of fish communities, the objective of this work was to evaluate the reproduction (verifying if there was reproductive activity and, if so, with what intensity) of the most abundant species of the fish community in Passa Cinco stream, in relation to the dry and wet season periods and to the longitudinal gradient, through the application of the reproductive intensity in$\operatorname{dex}(\mathrm{RII})$.

\section{Material and Methods}

The present study was accomplished in Passa Cinco stream, which is one of the main rivers of the Corumbataí River sub-basin. Its headwater is located in Serra da Cachoeira (with an altitude of $1000 \mathrm{~m}$ ), a component of the complex of Serra de Itaqueri, in the municipal district of Itirapina and its mouth is located in Corumbataí River (at an altitude of $480 \mathrm{~m}$ ). The drainage area of Passa Cinco Stream is $525 \mathrm{~km}^{2}$, travelling about $60 \mathrm{~km}$ from the headwater to its mouth (Garcia et al., 2004). Nowadays, it possesses $51.72 \%$ of its surface occupied by areas of implanted pasture, $14.13 \%$ for sugarcane, $15.67 \%$ for native forest and $0.74 \%$ for scrubland (Valente, 2001).

Six samplings were accomplished in five different points in Passa Cinco stream, contemplating sites of orders two, three, four, five and six (with the following geographical coordinates in UTM: site 1 (order 2) - 202954/7521189, site 2 (order 3) - 206116/752358, site 3 (order 4$)-210805 / 752454$, site 4 (order 5) 219726/7518957 and site 5 (order 6) - 226551/7507580) in the months of May, July, September and November of 2005 and January and March of 2006 (Figure 1).

The data of rainfall and air temperature during the sampling period were obtained at CEAPLA (Centre of Analysis and Environmental Planning), of Universidade Estadual Paulista, in Rio Claro.

The fishery equipment used was: a sieve, electric fishery equipment, gill nets (with mesh sizes varying from 3 to $9 \mathrm{~cm}$ between adjacent knots) and fish-traps. A sieve was used on bank vegetation for ten times in each sample site (except for sample site 1, due to the local characteristics: lack of marginal vegetation and low water volume). The electric fishery equipment connected to a generator with maximum capacity of $1500 \mathrm{v}$ and $60 \mathrm{~Hz}$, was used in samples sites 1, 2 and 3. In these places, the passages of $50 \mathrm{~m}$ were determined, where the equipment was placed for a single time, without a contention net. The gill nets were used in samples sites 3, 4 and 5; the sequence of gill nets was determined at random and remained submerged from the end of the day until the next morning. Two fish-traps (length $=50 \mathrm{~cm}$ 


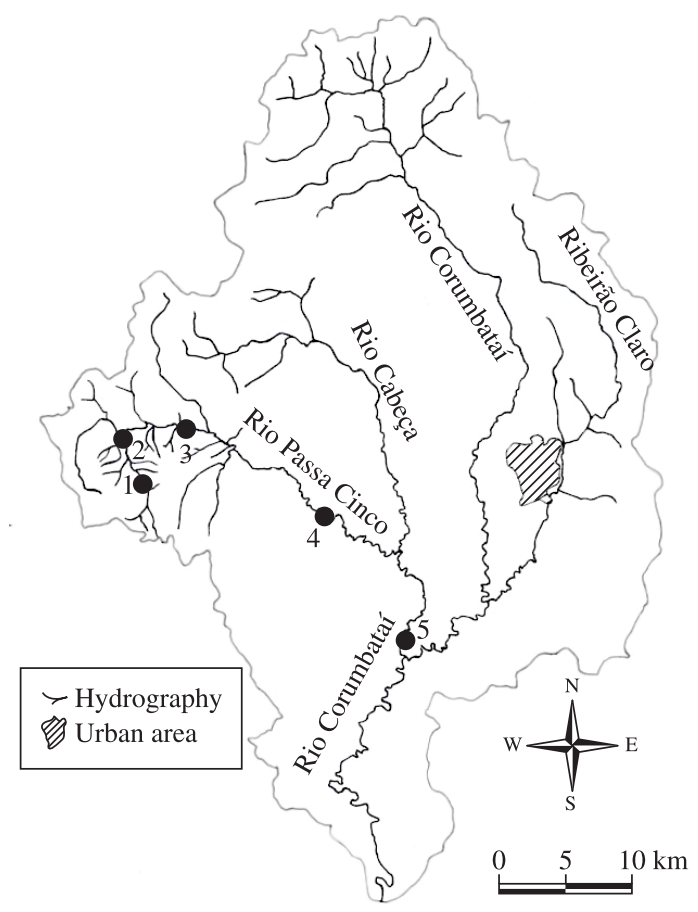

Figure 1. Hydrographic map of the Corumbataí River subbasin, showing the sampled sites (modified from Garcia et al., 2004). 1- Sample site 1; 2 - Sample site 2; 3 - Sample site 3; 4 - Sample site 4; and 5 - Sample site 5.

and diameter $=20 \mathrm{~cm}$ ) were used in the whole sample sites.

After each one of the samplings, the fishes were put into plastic bags, and afterwards they were fastened in formalin $10 \%$ for 2 days and later transferred to alcohol $70 \%$ until the accomplishment of the analysis.

In the laboratory, the fishes were identified until species level and the following data were taken: total and standard length in centimetres, total weight in grams, sex and state of gonadal maturation (Braga, 1990). The gonadal stage was determined using a stereomicroscope, or when possible, macroscopically, considering the following traits: colour, transparency, surface blood vessels, and oocytes aspect. According to a previously established scale, gonadal stages were classified into four categories: $\mathrm{A}=$ immature, $\mathrm{B}=$ in maturation or resting, $\mathrm{C}=$ mature and D = empty (Vazzoler, 1996).

Voucher specimens were deposited in the icththyological collection of the ichthyology laboratory of the Universidade Estadual Paulista, in Rio Claro.

Reproduction intensity in the community was evaluated by means of the reproductive intensity index (RII) (Vazzoler, 1996), based on the association between the frequency of females at each different maturity stage and the values of the gonadossomatic relationship, whereby an estimate can be taken concerning which reproduction intensity will occur in these environments.
The most abundant species that contained frequency of individuals with mature gonads of up to 10 per cent was considered in this analysis. The reproductive intensity of spawn populations was analysed by period (dry and wet seasons) and sample sites (but due to the insufficient number of mature females captured in sample sites 4 and 5, those sites were not included in that analysis).

For a possible classification of the most abundant species in reproductive categories by period (dry and wet seasons) and sample sites (stream order), the following steps were performed: a) estimate of the frequency of individuals with gonads in each stages during the whole period for the most abundant species; b) estimate of the frequency of females with mature gonads by period and sample site in relation to the other gonadal stages; c) sum of the medium values of the gonadossomatic relationship for mature females by period and sample site; d) estimate of the medium values of the gonadossomatic relationship (in percentage) by period and sample site; e) estimate of the reproductive categories in function of the mature females frequency and the percentage of GR maxima, by period and sample sites, considering: massive spawn (MS) when the percentages of mature females and GR maxima were elevated; occasional spawn (OS) when the percentage of mature females was low and the percentage of GR maxima was elevated; incipient maturation (IM) when the percentage of mature females was elevated and the percentage of GR maxima was low, and no reproductive activity (NRA) when the percentages of mature females and GR maxima were low. To perform the last step, the following values were considered high: the mature gonads frequency $(\% \mathrm{C})$ up to $15 \%$ and the maxima gonadossomatic relationship ( $\left.\% \mathrm{GR}_{\max }\right)$ up to $10 \%$.

To quantify the reproductive intensity of the species by periods and samples sites, the reproductive intensity index (RII) was calculated:

$\mathrm{RII}=\frac{\Sigma\left(\mathrm{WN}_{\mathrm{sp}}\right)}{\Sigma \mathrm{N}_{\mathrm{sp}}}$

where: $\mathrm{N}_{\mathrm{sp}}=$ number of species by category, $\mathrm{W}=4$ for the massive spawn, $\mathrm{W}=2$ for the occasional spawn, $\mathrm{W}=1$ for the incipient maturation and $\mathrm{W}=0$ for no reproduction.

From data on the standard length and gonadal maturation, the proportion of juveniles and adults was found, and, when possible, the length at sexual maturity was estimated $\left(\mathrm{L}_{50}\right)$, which corresponds to the estimated length at which $50 \%$ of the individuals reach maturity (Vazzoler, 1996), obtained by plotting on graphs the adult length classes and by estimating the median values.

Associating the RII of each species with the percentage of juveniles and adults found, it is possible to characterise the kind of use that the species make of the system: reproduction collective area (when RII was high and the percentage of juveniles was less than the adults) and feeding-growth area (when RII was low and the percentage of juveniles was greater than the percentage of adults). 


\section{Results}

Through the rainfall level and air temperature data obtained during the study, two periods were identified: the dry season, taking the first three samples (May, July and September 2005) and the wet season, taking the last three samplings (November 2005 and January and March 2006) (Figure 2).

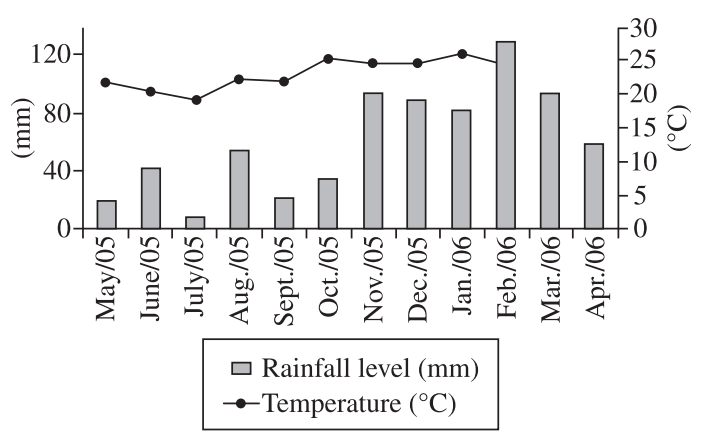

Figure 2. Distribution of monthly medium values of air temperature and monthly medium values of rainfall level in the sampling period (May of 2005 to April of 2006).
The frequency of individuals with gonads in different maturity stages (A, B, C and D) for the most abundant species and whole sample period is shown in Table 1. Through the frequency of individuals with mature gonads (stage $\mathrm{C}$ ), it is possible to suggest that the species, except for Hypostomus strigaticeps, perform reproduction in that system. So, H. strigaticeps was excluded from the analysis.

Characidium aff. zebra, Astyanax sp., Trichomycterus sp., Imparfinis mirini, Bryconamericus turiuba, Cetopsorhamdia iheringi, Corumbataia cuestae, Apareiodon ibitiensis, Parodon nasus, Imparfinis borodini, Piabina argentea and Rhamdia quelen were the species that presented more than ten females for each period and they had the reproduction intensity evaluated by sampling period.

Table 2 shows the frequency of females with mature gonads, the medium value of gonadossomatic relationship (GR), the transformation in percentage of the gonadossomatic relationship maxima (\%GR) and the reproductive categories of the considered species by sampling period.

For the dry period, the species that were included in the reproductive category "no reproductive activity" were Characidium aff. zebra, Trichomycterus sp., Imparfinis

Table 1. Frequency of maturity gonadal stages of the abundant species in the system during the whole sampling period and sampling sites $(\mathrm{N}=$ number of captured individuals, $\% \mathrm{~A}=$ percentage of individuals with immature gonads, $\% \mathrm{~B}=$ percentage of individuals with gonads in development, $\% \mathrm{C}=$ percentage of individuals with mature gonads, $\% \mathrm{D}=$ percentage of individuals with empty gonads).

\begin{tabular}{lccccc}
\hline \multicolumn{1}{c}{ Species } & & \multicolumn{4}{c}{ Maturity gonadal stages } \\
\cline { 4 - 6 } & N & \%A & \% B & \% C & \% D \\
\hline Characidium aff. zebra Eigenmann, 1909 & 933 & 0.98 & 63.56 & 31.06 & 4.39 \\
Phalloceros caudimaculatus Hensel, 1868 & 579 & 23.77 & 4.07 & 72.18 & 0 \\
Astyanax sp. & 373 & 8.65 & 53.24 & 31.62 & 6.49 \\
Hypostomus strigaticeps (Regan, 1908) & 360 & 10.9 & 83.46 & 5.64 & 0 \\
Trichomycterus sp. & 343 & 12.61 & 68.62 & 18.77 & 0 \\
Bryconamericus stramineus Eigenmann, 1908 & 268 & 5.38 & 77.31 & 17.31 & 0 \\
Odontostilbe microcephala Eigenmann, 1907 & 248 & 0 & 34.73 & 39.33 & 25.94 \\
Imparfinis mirini Hasemann, 1911 & 231 & 6.64 & 55.31 & 37.17 & 0.88 \\
Bryconamericus turiuba & 189 & 19.2 & 28.8 & 47.5 & 4.5 \\
Langeani, Lucena, Pedrini and Tarelho-Pereira, 2005 & & & & & \\
Astyanax scabripinnis paranae Eigenmann, 1914 & 186 & 14.84 & 19.78 & 51.1 & 14.29 \\
Cetopsorhamdia iheringi Schubart and Gomes, 1959 & 174 & 16.57 & 58.58 & 23.67 & 1.18 \\
Corumbataia cuestae Britski, 1997 & 158 & 7.74 & 52.26 & 40 & 0 \\
Astyanax altiparanae Garutti and Britskii, 2000 & 158 & 1.32 & 50.99 & 30.07 & 8.61 \\
Apareiodon ibitiensis Campos, 1944 & 110 & 12.96 & 38.89 & 45.37 & 2.78 \\
Paradon nasus Kner, 1859 & 98 & 3.16 & 58.95 & 32.63 & 5.26 \\
Astyanax bockmanni Vari and Castro 2007 & 85 & 5 & 43.75 & 46.25 & 5 \\
Corydoras flaveolus Ihering, 1911 & 73 & 1.35 & 20.27 & 78.38 & 0 \\
Imparfinis borodini Mees and Cala, 1989 & 69 & 19.4 & 62.69 & 17.91 & 0 \\
Piabina argentea Reinhardt, 1867 & 56 & 3.77 & 9.4 & 67.9 & 18.9 \\
Rhamdia quelen (Quoy and Gaimard, 1824) & 54 & 3.92 & 58.82 & 37.25 & 0 \\
\hline
\end{tabular}


Table 2. Frequency of females with mature ovaries (\% C), medium values of GR and of $\%$ GR, and reproductive categories $(\mathrm{RC})$ of the chosen species by collection period (NRA = no reproductive activity; IM = incipient maturation and $\mathrm{MS}=$ massive spawn) for the species that presented female $\mathrm{n}>10$ for collection period (Dry and Wet season)

\begin{tabular}{lccclcccc}
\hline & \multicolumn{4}{c}{ Dry season } & \multicolumn{5}{c}{ Wet season } \\
\hline \multicolumn{1}{c}{ Species } & \% C & GR & \%GR max & RC & \%C & RGS & \%GR max & RC \\
\hline Characidium aff. zebra & 6.7 & 0.01 & 2.5 & NRA & 100 & 2.29 & 13.4 & MS \\
Astyanax sp. & 42.5 & 0.4 & 12.1 & MS & 8.7 & 0.01 & 4.2 & NRA \\
Trichomycterus sp. & 14.8 & 1.76 & 8.5 & NRA & 23.7 & 3.33 & 15.4 & MS \\
Imparfinis mirimi & 4.25 & 0.01 & 2.1 & NRA & 64.4 & 0.54 & 29.8 & MS \\
Bryconamericus turiuba & 94.7 & 0.95 & 7.3 & IM & 25 & 0.06 & 1.7 & IM \\
Cetopsorhamdia iheringi & 0 & - & - & NRA & 34.3 & 0.09 & 13.2 & MS \\
Corumbataia cuestae & 20.8 & 0.22 & 6 & IM & 62 & 6.76 & 75.9 & MS \\
Apareiodon ibitiensis & 55.3 & 0.58 & 26.6 & MS & 60 & 0.23 & 30.3 & MS \\
Parodon nasus & 21.9 & 0.02 & 11.8 & MS & 64.5 & 1.1 & 35 & MS \\
Imparfinis borodini & 15.4 & 0.03 & 8.6 & IM & 16.7 & 0.09 & 13.9 & MS \\
Piabina argentea & 68.2 & 0.43 & 34.5 & MS & 67.7 & 0.07 & 11.3 & MS \\
Rhamdia quelen & 21.4 & 0.06 & 14.3 & MS & 43.8 & 0.23 & 9.9 & IM \\
\hline
\end{tabular}

Table 3. Frequency of females with mature ovaries (\% C), medium values of GR and of $\% \mathrm{GR}$, and reproductive categories $(\mathrm{RC})$ of the chosen species by collection site $(\mathrm{NRA}=$ no reproductive activity; $\mathrm{IM}=$ incipient maturation and $\mathrm{MS}=$ massive spawn) for the species that presented female $n>10$ for collection site.

\begin{tabular}{|c|c|c|c|c|c|c|c|c|c|c|c|c|}
\hline \multirow[b]{2}{*}{ Species } & \multicolumn{4}{|c|}{ Site 1} & \multicolumn{4}{|c|}{ Site 2} & \multicolumn{4}{|c|}{ Site 3} \\
\hline & $\% \mathrm{C}$ & GR & $\begin{array}{c}\text { \%GR } \\
\max \end{array}$ & $\mathbf{R C}$ & $\% \mathrm{C}$ & GR & $\begin{array}{c}\% \text { GR } \\
\max \end{array}$ & $\mathbf{R C}$ & $\% \mathrm{C}$ & GR & $\begin{array}{c}\% \text { GR } \\
\max \end{array}$ & $\mathbf{R C}$ \\
\hline Characidium aff. zebra & 27.1 & 1.56 & 16.35 & MS & 36.5 & 1.66 & 11.1 & MS & 26.8 & 1.06 & 7.4 & IM \\
\hline Astyanax sp. & 32.2 & 0.14 & 8.86 & $\mathrm{IM}$ & 45.7 & 0.51 & 15.3 & MS & 26.7 & 0.29 & 16.9 & MS \\
\hline Trichomycterus sp. & 18.2 & 2.06 & 9.95 & IM & 25 & 4.21 & 20.9 & MS & 12.5 & 1.89 & 8.7 & NRA \\
\hline Imparfinis mirini & 34 & 0.21 & 9.42 & $\mathrm{IM}$ & 35.3 & 0.35 & 12.15 & MS & 48 & 44 & 18.5 & MS \\
\hline Bryconamericus turiuba & $*$ & - & - & $*$ & 62.3 & 2.36 & 10.35 & MS & 50.8 & 0.4 & 16.4 & MS \\
\hline Cetopsorhamdia iheringi & 10.3 & 0.06 & 8.8 & NRA & 0 & - & - & $*$ & 21.4 & 0.04 & 9.3 & IM \\
\hline Corumbataia cuestae & $*$ & - & - & $*$ & 52 & 6.37 & 71.6 & MS & 57 & 1.22 & 11.9 & MS \\
\hline Apareiodon ibitiensis & $*$ & - & - & $*$ & 55.5 & 6.25 & 68.5 & MS & 64.1 & 5.14 & 32.3 & MS \\
\hline Piabina argentea & * & - & - & * & 62.3 & - & 11.9 & MS & 76.2 & 3.17 & 16.2 & MS \\
\hline
\end{tabular}

* Insufficient number of females captured in the point.

mirini and Cetopsorhamdia iheringi; Bryconamericus turiuba, Corumbataia cuestae and Imparfinis borodini were classified in "incipient maturation"; the other species - Astyanax sp., Apareiodon ibitiensis, Parodon nasus, Piabina argentea and Rhamdia quelen - belonged to "massive spawn". In the wet season, only Astyanax sp. represented the category "no reproductive activity"; Bryconamericus turiuba and Rhamdia quelen related to the category "incipient maturation"; the other species Characidium aff. zebra, Trichomycterus sp., Imparfinis mirini, Cetopsorhamdia iheringi, Corumbataia cuestae, Apareiodon ibitiensis, Parodon nasus, Imparfinis borodini and Piabina argentea - were classified in "massive spawn". The values of the reproductive intensity index by periods were 2.86 for the dry and 3.17 for the wet season.

The reproduction intensity analysis, by samples sites, was carried out for the following species: Characidium aff. zebra, Astyanax sp., Trichomycterus sp., Imparfinis mirini, Bryconamericus turiuba, Cetopsorhamdia iheringi, Corumbataia cuestae, Apareiodon ibitiensis and Piabina argentea, that presented more than ten females caught by sample site.

The frequency of females with mature gonads, the medium value of gonadossomatic relationship (GR), the transformation in percentage of the gonadossomatic relationship maxima (\%GR) and the reproductive categories of the considered species by sample site are shown in Table 3.

In sample site 1, Astyanax sp., Trichomycterus sp. and Imparfinis mirini were classified in category "incipient maturation", Characidium aff. zebra belonged to the category "massive spawn" and Cetopsorhamdia iheringi was representative of category "no reproductive activity". In sample site 2 , the whole species considered were classified in "massive spawn". In sample site 3, Trichomycterus sp. belonged to "no reproductive activity"; Characidium aff. zebra and Cetopsorhamdia 
Table 4. Medium length at sexual maturity $\left(\mathrm{L}_{50}\right)$, frequency of juvenile $(\% \mathrm{~J})$ and adults $(\% \mathrm{~A})$ phases and number of analysed individuals $(\mathrm{N})$ for the chosen species considering the whole period and all sampling sites

\begin{tabular}{lcclc}
\hline \multicolumn{1}{c}{ Species } & $\begin{array}{c}\mathbf{L}_{\mathbf{5 0}} \\
(\mathbf{c m})\end{array}$ & $\mathbf{\%} \mathbf{J}$ & $\mathbf{\%} \mathbf{A}$ & $\mathbf{N}$ \\
\hline Characidium aff. zebra & $*$ & 1 & $99 * *$ & 928 \\
Astyanax sp. & $*$ & 8.6 & $91.4 * *$ & 371 \\
Trichomycterus sp. & 4.2 & 12.5 & $87.5 * *$ & 343 \\
Imparfinis mirini & $*$ & 6.5 & $93.5 * *$ & 231 \\
Bryconamericus turiuba & 4.6 & 19 & $81 * *$ & 179 \\
Cetopsorhamdia iheringi & 3.7 & 16.4 & $83.6 * *$ & 171 \\
Corumbataia cuestae & $*$ & 7.8 & $92.2 * *$ & 154 \\
Apareiodon ibitiensis & 5.4 & 12.7 & $87.3 * *$ & 109 \\
Parodon nasus & $*$ & 3.1 & $96.9 * *$ & 98 \\
Imparfinis borodini & 5.5 & 18.8 & $81.2 * *$ & 69 \\
Piabina argentea & $*$ & 3.8 & $96.2 * *$ & 53 \\
Rhamdia quelen & $*$ & 5.7 & $94.3 * *$ & 53 \\
\hline It was not & &
\end{tabular}

* It was not possible to determine the $\mathrm{L}_{50}$ due to the insufficient number of collected immature individuals.

** Predominance of adults which isolated, may suggest a reproduction area of the species.

iheringi were classified as "incipient maturation"; and the other species belonged to "massive spawn". The values of reproductive intensity index by samples sites were: 0.78 for site $1,3.56$ for site 2 and 2.89 for site 3 .

The percentages of juveniles and adults and the medium length at sexual maturity $\left(L_{50}\right)$ are shown in Table 4. For the whole species considered, the adult percentage exceeded that of the juveniles.

When the values of reproduction intensity índex (RII) were combined with the percentages of juveniles and adults, it is possible to determine the use of the system by the species. Due to the mean value of RII and the predominance of adults, the samples sites were used as reproductive and foraging sites by the studied species.

\section{Discussion}

Inside the same stream, the synchrony and the duration of reproduction can differ among species (Winemiller, 1989), suggesting the action of biotic or environmental factors acting on aspects of reproduction (Alkins-Koo, 2000; Paugy, 2002). Each species presents, within the reproductive period, particular demands on water quality, food availability and refuges that guarantee the individuals survival in the initial phases of the development (Vazzoler, 1996).

Most of the species displays a periodicity in its reproductive process, beginning its gonadal development in a time previous to that of reproduction, and completing its gonadal maturation when the environmental conditions are appropriate to fecundation and offspring development (Vazzoler, 1996). June (1977) discusses the reproductive patterns found in some species of fish, and draws attention to the regularity of spawning, affirming the existence of a fundamental connection between the physiologic rhythm of the fish and environmental factors.

According to Vazzoler and Menezes (1992), the reproductive period for the species of the Paraná River basin begins in October, when the temperature is elevated and the water level begins to rise, reaching the peak in December-January, when the rainfall level is high. That information matches with the values of the reproductive intensity index calculated by period, which indicated the wet season (November to March) as the period when most of the species reproduced.

When the reproductive intensity index was calculated by sample site (considering the first three points), site 2 was the point that presented the highest value, showing it to be the main reproduction place for most of the species. It is very likely that this point was the place, along the whole system, that presented the most appropriate conditions for reproduction, in relation to the availability of shelter, food and so on.

Vazzoler (1996) defines that a species classified as "massive spawn" is the one that, with a significant portion of the population, completely presents maturation evidence, with a high probability that spawning occurs in the system; in the "occasional spawn" a small population portion presents evidence of probable spawning in the system; in "incipient maturation", a significant population portion presents mature gonads, but there is no evidence that spawning can happen; and the category "no reproductive activity" is one in which a significant portion does not present mature gonads or individuals with mature gonads do not occur.

So, considering the dry period, only four of the twelve considered species didn't present evidence of reproduction (Characidium aff. zebra, Trichomycterus sp., Imparfinis mirini and Cetopsorhamdia iheringi). The other species presented individuals with mature gonads, some species with enough numbers to evidence reproduction in the dry period. In the wet season, only Astyanax sp. did not present enough numbers of mature individuals, not characterising that period as reproductive. The other species either presented reproduction evidence or, despite the existence of mature individuals, it was not possible to affirm, with certainty, that the species reproduced in the system in that period.

When considering the samples sites, site 2 was the one where all the species analysed were framed in the category massive spawn, indicating that those species reproduce at that place, according to the value of the reproductive intensity index found for this sampling site.

The length at sexual maturity $\left(\mathrm{L}_{50}\right)$ is quite a labile reproductive tactic, being intimately related to genotypeenvironmental interaction and, consequently, to growth, presenting variations space and temporary intraspecifics depending on the prevalent biotic and abiotic environmental conditions (Vazzoler et al., 1997). The $\mathrm{L}_{50}$ found for the species was around $5.5 \mathrm{~cm}$, showing a reduced 
length for mature individuals, as found by Gomiero and Braga (2007).

The juveniles' proportion and adults estimated from the medium lengths of the first gonadal maturation and/ or of the distributions of length classes provide subsidies to complement the evidence for the kind of use that the community makes of the system (Vazzoler, 1996). The prevalence of adult individuals indicates the use of the system as a reproduction area, while the largest proportion of juveniles indicates that the area is used for feeding and growth.

The analysed species presented prevalence of adults, which suggests, separately, that those species use the system as reproduction area. However, when that information was crossed with the values of GR, which presented intermediate values, it was possible to conclude that the system is used by the species as much as a reproduction area as a feeding area.

Gomiero and Braga (2007) obtained a similar result for the populations analysed in the basins of the rivers Corumbataí and Jacaré-pepira. Braga (2001) verified that the dominant species of tributaries of the reservoir of Volta Grande use the area for reproduction.

The characteristics of the fishery equipment used might have impaired the capture of juveniles. In the beginning of the wet season's samplings, the juveniles Trichomycterus sp. were observed in site 1; those individuals met agglomerates and semi-buried at a place of low current and sand bottom. That is a great indication that species reproduced in the system and that the place is used by the juveniles for feeding and growth.

The integrity of reproduction areas and feeding is essential for the maintenance of the stocks of fish, taking into consideration the importance for the dispersion of the eggs and larvaes and development and growth of juveniles, making the recruitment possible. Before that, the identification of those areas is essential for measures of protection and management of the ichthyofauna.

Acknowledgements - The authors would like to thank FAPESP for the Master's scholarship conceded to the first author (proc. $\mathrm{n}^{\circ}$ 04/12669-3), IBAMA (proc. $\mathrm{n}^{\circ} 02027.000234 / 2005-05$ ) for authorising the license for the execution of field works, and the designer, Jaime R. Somera, for map confection.

\section{References}

ALKINS-KOO, M., 2000. Reproductive timing of fishes in a tropical intermittent stream. Environmental Biology of Fishes, vol. 57, p. 49-66.

AZEVEDO, CO., BARBIERI, MC. and BARBIERI, G., 1988a. Ciclo reprodutivo de Parodon tortuosus (Eigenmann \& Norris, 1900) do Rio Passa Cinco Ipeúna-SP. Revista Brasileira de Biologia = Brazilian Journal of Biology, vol. 48, no. 3, p. 565-569. (parte I, Estádios de maturação dos testículos: época de reprodução).

1988b. Ciclo reprodutivo de Parodon tortuosus (Eigenmann \& Norris, 1900) do Rio Passa Cinco Ipeúna-SP. Revista Brasileira de Biologia = Brazilian Journal of Biology, vol. 48 , no. 3 , p. 571-575. (parte II, Estádios de maturação do ovário: época de reprodução).

BARBIERI, G., VERANI, JR. and BARBIERI, MC., 1983. Análise do comportamento reprodutivo das espécies Apareiodon affinis (Steindachner, 1879), Apareiodon ibitiensis Campos, 1944 e Parodon tortuosos Eigenman and Norris, 1900 do rio Passa Cinco, Ipeúna-SP. In Anais do III Seminário Regional de Ecologia. São Carlos: USP. p. 189-199.

BARBIERI, G., VERANI, JR., PEREIRA, JA., BARBIERI, MC., PERET, AC. and MARINS, MA., 1985. Curva de maturação e fator de condição de Apareidon affinis (Steindachner, 1979), Apareidon ibitiensis (Campos, 1944) e Parodon tortuosos (Eigenman and Norris, 1900) do Rio Passa Cinco, Ipeúna, SP. Ciência e Cultura, vol. 37, no. 7, p. 1178-1183.

BARBIERI, G. and BARBIERI, MC., 1989. Growth and first maturation size of Parodon tortuosos Eigenmann and Norris, 1900 from Passa Cinco river (Ipeúna, São Paulo State, Brazil) (Osteichthyes, Parodontidae). Naturalia, vol. 14, p. 45-54.

BRAGA, FMS., 1990. Aspectos da reprodução e alimentação de peixes comuns em um trecho do rio Tocantins entre Imperatriz e Estreito, Estado do Maranhão e Tocantins, Brasil. Revista Brasileira de Biologia $=$ Brazilian Journal of Biology, vol. 50, no. 3 , p. 547-558.

2001. Reprodução de peixes (Osteichthyes) em afluentes do reservatório de Volta Grande, Rio Grande, Sudeste do Brasil. Iheringia, Série Zoologia, no. 91, p. 67-74

BYE, VJ., 1984. The role of environmental factors in the timing of reproductive cycles. In WOOTTON, RJ. Fish reproduction strategies and tactics. New York: Chapman \& Hall.

CARMASSI, AL., 2008. Variação espaço-temporal na composição da comunidade de peixes do Rio Passa Cinco (SP). Rio Claro: Universidade Estadual Paulista. [Dissertação de Mestrado].

CETRA, M., 2003. Caracterização das assembléias de peixes da bacia do rio Corumbataí. São Carlos: Universidade de São Paulo. [Tese de Doutorado].

CORVALÁN, SB., 2005. Levantamento e carcterização dos atrativos naturais da bacia do rio Passa Cinco, através de geoprocessamento. Rio Claro: Universidade Estadual Paulista. [Dissertação de Mestrado].

FERREIRA, A., 2004. Ecologia trófica de Astyanax paranae (Osteichthyes, Characidae) em córrego da bacia do Rio Passa Cinco, Estado de São Paulo. Piracicaba: Universidade de São Paulo. [Dissertação de Mestrado].

FRAGOSO, EN., 2005. Ictiofauna da microbacia do córrego da Lapa, bacia do Alto Paraná, Itirapina/Ipeúna, SP. São Carlos: Universidade Federal de São Carlos. [Tese de Doutorado].

GERHARD, P., 2005. Comunidades de peixes de riachos em função da paisagem da bacia do Rio Corumbataí, Estado de São Paulo. Piracicaba: Universidade de São Paulo. [Tese de Doutorado].

GOMIERO, LM., 2003. Estudo biológico das populações de peixes na Área de Proteçâo Ambiental das cuestas de São Pedro e Analândia (SP). Rio Claro: Universidade Estadual Paulista. [Tese de Doutorado].

GARCIA, GJ., HEBERT, HD., PERINOTTO, JAJ. and CASTRO, JFM., 2004. Atlas ambiental da bacia do rio Corumbataí. Rio 
Claro: Universidade Estadual Paulista. Available from: <http:// www.rc.unesp.br/>. Access in: 13/03/2004.

GOMIERO, LM. and BRAGA, FMS., 2007. Reproduction of fish assemblages in the state of São Paulo, southeastern Brasil. Revista Brasileira de Biologia = Brazilian Journal of Biology, vol. 67 , no. 2, p. 283-292.

JUNE, FC., 1977. Reproductive patterns in seventeen species of warmwater fishes in a Missouri River reservoir. Environmental Biology of Fishes, vol. 2, no. 3, p. 285-296.

LOWE-McCONNELL, RH., 1999. Estudos ecológicos em comunidades de peixes tropicais. São Paulo: USP.

NIKOLSKY, GV., 1963. The ecology of fishes. London: Academic Press. 325 p.

PAUGY, D., 2002. Reproductive strategies of fishes in a tropical temporary stream of the Upper Senegal basin: Baoulé River in Mali. Aquatic Living Resources, vol. 15, p. 25-35.

RONDINELI, GR., 2007. Biologia alimentar e reprodutiva na comunidade de peixes do Rio Passa Cinco (SP). Rio Claro: Universidade Estadual Paulista. [Dissertação de Mestrado].

VALENTE, ROA., 2001. Análise da estrutura da paisagem na bacia do Rio Corumbataí, SP. Piracicaba: Universidade de São Paulo. [Dissertação de Mestrado].
VAZZOLER, AEAM., 1996. Biologia da reprodução de peixes teleósteos: teoria e prática. Maringá: EDUEM. 167 p.

VAZZOLER, AEAM. and MENEZES, NA., 1992. Síntese de conhecimento sobre comportamento reprodutivo de Characiformes da América do Sul (Teleostei, Ostariophysi). Revista Brasileira de Biologia $=$ Brazilian Journal of Biology, vol. 52 , no. 4 , p. 627-640.

VAZZOLER, AEAM., SUZUKI, HI., MARQUES, EE. and LIZAMA, MAP., 1997. Primeira maturação gonadal, períodos e áreas de reprodução. In VAZZOLER, AEAM., AGOSTINHO, AA. and HANH, NS. (Eds.). A planície de inundação do alto Rio Paraná: aspectos físicos, biológicos e socioeconômicos. Maringá: EDUEM.

VIADANNA, AG., 1992. Perfis ictiobiogeográficos da bacia do Rio Corumbataí, SP. São Paulo: Universidade de São Paulo. [Tese de Doutorado].

WINEMILLER, KO., 1989. Patterns of variation in life history among South American fishes in seasonal environments. Oecologia, vol. 81, p. 225-241.

WOOTTON, RJ., 1984. Introduction: strategies and tactics in fish reproduction. In POTTS GW. and WOOTTON, RJ. (Eds.). Fish Reproduction strategies and tactics. Orlando: Academic Press. p. 1-12.

1989. Ecology of teleost fishes. Boston: Kluwer Academic Publishers. 